\title{
PRODUKSI DAN LAJU DEKOMPOSISI SERASAH MANGROVE BERDASARKAN TINGKAT KERAPATANNYA DI DELTA SUNGAI WULAN, DEMAK, JAWA TENGAH
}

Production and Rate Manure Decomposition Based of density level Mangrove at Delta Wulan River, Demak, Central Java

Sena Widhitama, Pujiono Wahyu Purnomo *), Agung Suryanto

Program Studi Manajemen Sumberdaya Perairan

Fakultas Perikanan dan Ilmu Kelautan, Universitas Diponegoro

Jl. Prof. Soedarto, SH, Tembalang, Semarang, Jawa Tengah - 50275, Telp/Fax. +6224 7474698

Email :Senawidhitama.sw@gmail.com

\begin{abstract}
ABSTRAK
Salah satu proses pada ekosistem mangrove yang memberikan kontribusi besar terhadap kesuburan perairan adalah proses dekomposisi atau penghancuran serasah mangrove. Penghancuran serasah merupakan bagian dari tahap proses dekomposisi, yang dapat menghasilkan nutrient penting dalam rantai makanan, melalui produktivitas perairan disekitarnya, sebagaimana yang terjadi di Delta Sungai Wulan. Tujuan penelitian ini adalah untuk mengetahui produksi serasah mangrove dan laju dekomposisinya berdasarkan tingkat kerapatan mangrove.Metode yang digunakan adalah metode survai hal ini dilakukan dalam tiga titik sampling, yang dikelompokkan pada tiga kategori kerapatan mangrove yaitu rendah, sedang dan tinggi.Penelitian ini dilaksanakan pada bulan januari sampai maret 2016. Hasil penelitian menemukan tiga spesies mangrove yaitu Rhizopora mocrunata, Rhizopora apiculata, dan Avicennia marina. Jumlah serasah yang diperoleh pada kerapatan mangrove rendah adalah 701.51 gram, mangrove kerapatan sedang berjumlah 837.94 gram dan mangrove kerapatan tinggi berjumlah 1276.85 gram. Laju dekomposisi dalam 30 hari pengamatan dengan laju tertinggi berada pada mangrove kerapatan tinggi dengan persentase 29 - $30 \%$, sedangkan kerapatan mangrove rendah dan kerapatan mangrove sedang dengan persentase $28 \%$.
\end{abstract}

Kata kunci : Delta Sungai Wulan;Produksi Serasah;Laju Dekomposisi

\section{ABSTRACT}

One of the processes at mangrove ecosystem which contributes greatly to the fertility waters is the process of decomposition or destruction of mangrove manure. Destruction of Manure is a part of the decomposition process, can produce an important nutrient in the food chain, by means of productivity of the surroundings waters, as happened in Delta Wulan. The purpose of this study was to find out the mangrove manure production and the rate of decomposition is based on the density of mangrove. The method used is a survey method to divide the three point sampling, which grouped in three categories mangrove density, low, medium and high. This research was conducted in January to March 2016. The result of research to found three species of mangrove that Rhizopora mocrunata, Rhizophora apiculata and Avicennia marina. The amount of manure that is obtained at a low density is 701.51 grams, medium density amounted to 837.94 grams and high density mangrove amounted to 1276.85 grams. The rate of decomposition in the 30 days of observation by the highest rates are in the high density mangrove with a percentage of $29 \%-30 \%$, meanwhile low density mangrove and mangrove medium density with a percentage of $28 \%$.

Keywords : Delta Wulan River;Manure production;Decomposition rate

*) Penulis penanggungjawab

\section{PENDAHULUAN}

Perairan sekitar delta merupakan perairan yang subur karena di kawasan tersebut terjadi penumpukan nutrien maupun bahan organik yang berasal baik dari daratan maupun lautan yang terjebak atau terendapkan.Delta-delta yang ada di daerah tropis hampir seluruhnya ditumbuhi oleh mangrove.Hal tersebut seperti yang terlihat di beberapa delta besar di daerah tropis yang salah satunya terdapat di delta Wulan, Demak.

Hutan Mangrove di Delta Sungai Wulan, Demak tumbuh secara alami. Jenis mangrove yang ditemukan pada ekosistem sungai dari Delta Wulan yaitu 9 jenis yang didominasi oleh genus Rhizophora sp baik dalam bentuk Pohon, Semak, maupun bibit atau anakan (Sulistiowati,2004). Mangrove yang berada di Desa Menco, Kecamatan Wedung, Kabupaten Demak, Provinsi Jawa Tengah keadaannya masih terjaga tetapi pada bagian tertentu sudah mengalami kerusakan. Kerusakan yang terjadi disebabkan karena kawasan yang ditumbuhi

${ }^{\text {C }}$ Copyright by Management of Aquatic Resources (MAQUARES) 
mangrove digunakan untuk tambak oleh masyarakat setempat. Kondisi ini dikhawatirkan akan menurunkan fungsi dan peranan mangrove sebagai kawasan pengubah nutrient yang akhirnya mempengaruhi terhadap produktivitas ekosistem pesisir atau estuari, dalam mendukung ketersediaan sumberdaya ikan di perairan pesisir.

Penelitian mengenai laju dekomposisi di pandang pelu dilakukan karena poses ini merupakan awal dari proses rantai makanan. Dengan diketahuinya jatuhan serasah dan aktifitas dekomposisi dapat dipergunakan untuk menduga melalui proses produksi perairan berikutnya seperti dalam pemanfaatan sebagai daerah berkumpulnya larva ikan di dearah tersebutSalah satu proses yang terjadi pada ekosistem mangrove yang memberikan kontribusi paling besar terhadap kesuburan perairan adalah proses dekomposisi atau penghancuran serasah mangrove. Penghancuran serasah merupakan bagian dari tahap proses dekomposisi, yang dapat menghasilkan bahan organik yang penting dalam rantai makanan, memberikan kesuburan dan produktivitas perairan disekitarnya, terlebih lagi pada ekosistem delta Sungai Wulan sudah banyak hutan mangrove yang di alih fungsikan sebagai tambak ikan dan juga tambak garam yang luasnya cukup panjang karena penelitian mengenai produksi dan laju dekomposisi serasah daun mangrove di delta sungai Wulan belum pernah dilakukan, maka perlu dihitung berapa produksi dan laju dekomposisi serasah daun mangrove di delta sungai Wulan, dan perlu diketahui juga bahwa hanya serasah daun saja yang dikaji dalam penelitian ini.

Diharapkan dengan dilakukan penelitian ini dapat menjaga kelestarian ekosistem mangrove dari delta wulan yang dapat dipantau sehingga adanya kontrol terhadap ekosistem mangrove di delta sungai Wulan.Adanya penelitian yang berkelanjutan untuk dilakukan kontrol terhadap kerusakan dari ekosistem mangrove yang dihasilkan pada delta sungai Wulan sehingga dapat terjaga ekosistem dan dapat berfungsinya ekosistem mangrove.

\section{MATERI DAN METODE PENELITIAN}

\subsection{Materi}

Materi yang digunakan dalam penelitian ini adalah serasah mangrove yang terdiri dari daun,ranting, buah dan bunga. Dalam penelitian produksi serasah menggunakan semua serasah mangrove sedangkan untuk laju dekomposisi serasah yang digunakan hanyalah daun mangrove. Hal ini dikarenakan daun mangrove mengalami proses penguraian yang lebih cepat dibandingkan dengan ranting, buah atau bunga mangrove

\subsubsection{Alat dan Bahan.}

Litter trapdan Litter Bag yang diletakkan di dearah mangrove delta sungai wulan, demak. Variabel utama yang diukur dalam penelitian ini adalah :Tingkat Kerapatan Mangrove, Produksi serasah, Laju dekomposisi serasah, dan tekstur sedimen serta pengukuran penyusuran bahan organik serasah. Parameter pendukung fisika dan kimia yang diukur yaitu : Salinitas, $\mathrm{pH}$ dan Suhu Sedimen. Alat yang digunakan dalam penelitian ini adalah Litter trap, pengaris, refractometer, $\mathrm{pH}$ paper, Oven, Line transek, Kuadran transek, Timbangan elektrik, litter bag, furnice, crucible, desicator, gelas ukur, sieve net.

\subsection{Metode}

Metode penelitian ini bersifat eksploratif yaitu menggali informasi melalui tinda serdasarkan fenomena yang terjadi, selanjutnya didasarkan pembagian wilayah kajian menjadi 3 kelompok kerapatannya (rendah, sedang dan tinggi).Sebagai stasiun I, II, dan III. Prosedur kerja diawali dengan penentuan lokasi transek dengan cara observasi langsung di tempat penelitian di kawasan mangrove delta Wulan. Dalam hal ini yang diukur pada penentuan lokasi penelitian adalah status dari ekosistem mangrove yang dijadikan sebagai acuan untuk melakukan penelitian laju dekomposisi serasah mangrove .

\subsubsection{Prosedur pengamatan Ekosistem Mangrove}

\subsubsection{Prosedur pengamatan stasiun}

Menurut Bengen (2003), prosedur pengamatan dlakukan sebagai berikut:

Didaerah penelitian dibuat 3 stasiun dengan karakteristik yang berbeda.

1. Pada setiap stasiun pengamatan, terdapat 3 transek garis dari arah sungai ke arah darat (tegak lurus garis pantai sepanjang zonasi hutan mangrove yang terjadi) di daerah intertidal.

2. Di setiap transek garis diletakan secara acak plot berbentuk bujur sangkar dengan ukuran $10 \times 10 \mathrm{~m} 2$ sesuai lebar hutan mangrove.

3. Pada setiap plot yang telah ditentukan, hitung jumlah pohon mangrove untuk menghitung kerapatan pohon tiap stasiunnya .

4. Pada setiap zona sepanjang transek garis, ukur parameter lingkungan yang ditentukan dan pada setiap petak contoh (plot), amati dan catat tipe substrat.

\footnotetext{
${ }^{\text {C }}$ Copyright by Management of Aquatic Resources (MAQUARES)
} 


\subsubsection{Prosedur pengukuran produksi serasah}

Metode yang umum digunakan untuk pengambilan produksi serasah adalah metode litter-trap (jaring penampung serasah) (Brown, 1984) dalam Indriani (2008) yaitu :

1. Mengambil sampel serasah mangrove (daun, ranting, dan buah/bunga) menggunakan jaring yang berukuran 1 x $1 \mathrm{~m} 2$ yang diletakkan pada ketinggian $1-1,5 \mathrm{~m}$ atau setinggi dada.

2. Membentangkan jaring di bawah pohon mangrove, dengan lokasi sampling berukuran $10 \times 10 \mathrm{~m} 2$.

3. mengambil serasah selama 2 bulan dengan rentang waktu dua minggu sekali sebanyak 4 kali.

4. Memasukkan mangrove yang tertampung jaring ke dalam kantong plastik lalu diberi label, setelah itu dibawa ke laboratorium untuk ditimbang menggunakan timbangan elektrik (ketelitian 0,001gram) dalam produksi serasah dengan satuan gram/m2/minggu.

\subsubsection{Prosedur pengukuran laju dekomposisi serasah}

Prosedur pengukuran laju dekomposisi serasah yaitu:

1. Mengukur sampel laju dekomposisi diawali dengan pengeringan daun mangrove pada temperatur $60{ }^{\circ} \mathrm{C}$ sampai beratnya konstan menggunakan oven,

2. Mengambil sebanyak 30 gram daun kering mangrove kedalam kantong serasah dan diletakan di bawah pohon mangrove diikat dibawah akar pohon mangrove.

3. Mengambil sampel selama 15 hari sekali sebanyak 2 kali dalam waktu 1 bulan.

4. Daun mangrove yang di dalam kantong serasah dibawa ke laboratorium, daun tersebut dibersihkan dari lumpur maupun kotoran, setelah itu dikeringkan pada temperatur $105{ }^{\circ} \mathrm{C}$ sampai beratnya konstan dan ditimbang. Hasil untuk mengetahui penguraian yaitu berat kering awal dikurangi berat kering akhir. (Indriani,2008).

\subsubsection{Variable pengukuran fisika dan kimia sedimen}

Variable pengukuran fisikadan kimia pada sedimen meliputi suhu, salinitas, $\mathrm{pH}$ sedimen dan pengukuran tekstur sedimen. Seperti yang disajikan pada table 1. Pengukuran variable fisika dan kimia sedimen mangrove.

Tabel 1.Pengukuran variable fisika, kimia dan tektur sedimen serta pengukuran pengusutan bahan organik serasah.

\begin{tabular}{lllll}
\multicolumn{1}{c}{ serasah. } & & & \\
\hline No & Variabel & Satuan & Metode \\
\hline A & Tekstur Tanah & $\%$ & (Buchanan,1992) \\
& (Pasir, lumpur, liat) & & & \\
B & Fisika dan kimia & & (Wikkinson & dan \\
& sedimen & & Baker, 1994) & \\
& Suhu & ${ }^{\circ} \mathrm{C}$ & Termometer & \\
& Salinitas & $\mathrm{oo}^{\circ}$ & Refraktometer & \\
C & Bahan Organik & $\%$ & Gravimetri & \\
\hline
\end{tabular}

\subsection{Lokasi Penelitian}

Penelitian ini dilaksanakan pada bulan Januari 2016 sampai Maret 2016 dan stasiun penelitian berada pada ekosistem mangrove di Desa Menco, Kecamatan Wedung, Kabupaten Demak, Provinsi Jawa Tengah, sementara untuk analisis data produksi dan laju dekomposisi serasah mangrove dilaksanakan di Laboratorium Manajemen Sumberdaya Perairan, Laboratorium Hidrobiologi Fakultas Perikanan dan Ilmu Kelautan, UNDIP, Tembalang, Semarang.

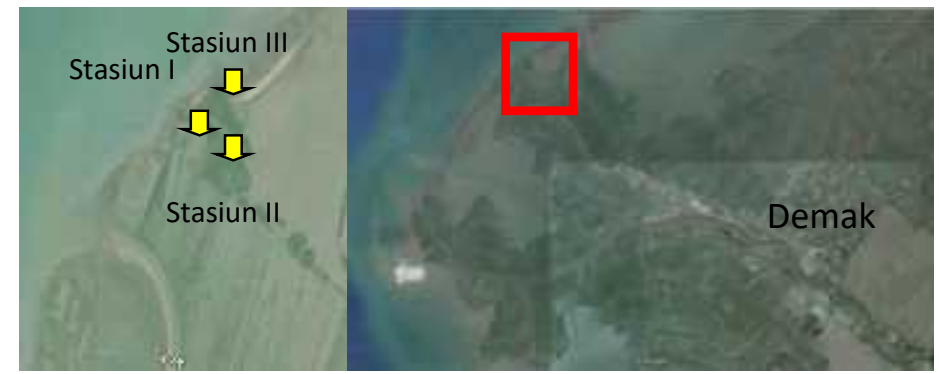

(Gambar 1. Lokasi Sampling Delta Sungai Wulan, Demak. Sumber : Google Maps, 2016) $100 \mathrm{~m}^{2}$ yaitu :

Lokasi penelitian ini dibagi menjadi 3 statiun yang didasarkan dengan tingkat kerapatan mangrove per 
Tabel 2. Titik Koordinat Lokasi Penelitian

$\begin{array}{ccc}\text { Stasiun 1 } & \text { Stasiun 2 } & \text { Stasiun 3 } \\ \text { S } 06^{0} 43^{\prime} 29.5^{\prime} & \text { S } 06^{0} 43^{\prime} 28.9^{\prime \prime} & \text { S } 06^{0} 43^{\prime} 29.8^{\prime \prime} \\ \text { E } 110^{0} 33^{\prime} 21.9^{\prime} & \text { E } 110^{0} 33^{\prime} 22.5^{\prime \prime} & \text { E } 110^{0} 33^{\prime} 23.3^{\prime \prime}\end{array}$

\subsection{Analisis Data}

Peubah utama pada penelitian ini adalah dekomposisi sehingga melakukan pengukuran secara periodik terhadap perubahannya antar tingkat kerapatan.Berdasarkan hal tersebut maka terdapat perubahan materi dekomposisi persatuan waktu dan persatuan perlakuan. Oleh karenanya uji yang digunakan adalah analisis peragam (Steel dan Torrie, 2009).

\subsubsection{Perhitungan produksi serasah}

Serasah mangrove yang jatuh ke jaring nylon berukuran 1 x $1 \mathrm{~m} 2$ kemudian dimasukkan ke kantong plastik.Pisahkan komponen daun, ranting, dan bunga-buah.Kemudian di timbang dengan ketelitian timbangan 0,001 gram.Hasil dari pengukuran dihitung dengan satuan gram $/ \mathrm{m} 2 / \mathrm{hari}$.

\subsubsection{Perhitungan laju dekomposisi serasah}

Perhitungan presentase laju dekomposisi mangrove per hari menggunakanrumus (Bonruang, 1984) :

$$
\mathrm{Y}=\frac{B A-B K}{B A} X 100 \%
$$

dimana:

$\mathrm{Y}=$ Presentase Serasah daun yang mengalami dekomposisi

$\mathrm{BA}=$ Berat Awal Penimbangan (gram)

$\mathrm{BK}=$ Berat akhir Penimbangan (gram)

\section{HASIL DAN PEMBAHASAN}

3.1. HASIL

Hasil yang didapat dari penelitian produksi dan laju dekomposisi serasah mangrove buıuasarkan tingkat kerapatannya di Delta Sungai Wulan, Demak, Jawa Tengah adalah sebagai berikut:

3.1.1.Karakteristik dan Kondisi Mangrove

Tabel 3.Jenis dan Kerapatan Mangrove (individu/100 m2) di Delta Sungai Wulan, Demak.

\begin{tabular}{llll}
\hline Stasiun & Jenis Mangrove & Diameter $(\mathbf{c m})$ & Batang \\
\hline 1 & Rhizopora apiculata & $10,25-31,25$ & 21 \\
& Avicennia marina & $8,47-18,5$ & 5 \\
& & Jumlah & $\mathbf{2 6}$ \\
& Rhizopora apiculata & $7,32-19,11$ & 15 \\
& Rhizopora mucronata & $11,14-30,5$ & 22 \\
& Avicennia marina & $6,34-24,5$ & 10 \\
& & Jumlah & $\mathbf{4 7}$ \\
& Rhizopora apiculata & $9,55-24,33$ & 47 \\
& Rhizopora mucronata & $10,5-23,2$ & 24 \\
& Avicennia marina & $9,75-14,67$ & 10 \\
& & Jumlah & $\mathbf{8 1}$ \\
\hline
\end{tabular}

Mangrove yang mendominasi daerah penelitian terdapat 2 spesies yaitu Avicennia sp dan juga Rhizopora sp. Diameter mangrove yang berada dilokasi penelitian pada desa Menco ini terdapat beberapa kategori dalam golongan mangrove yaitu golongan semai yang berdiameter kurang dari $10 \mathrm{~cm}$, golongan pancang yang memiliki diameter $10-25 \mathrm{~cm}$, golongan tiang yang memiliki diameter $26-35 \mathrm{~cm}$. Berdasarkan data tersebut tidak ditemukannya mangrove yang termasuk dalam golongan pohon yang memiliki diameter lebih dari $36 \mathrm{~cm}$.

\subsubsection{Produksi Serasah Mangrove}

Pengambilan serasah mangrove dilakukan selama 5 minggu yang dilakukan secara akumulatif pada pengambilan dalam 2 minggu. Hasil pengukuran produksi serasah organik berdasarkan tingkat kerapatan mangrove memiliki penilaian pada Tabel 4 sebagai berikut :

Tabel 4. Hasil Produksi Total Serasah Mangrove (gram) di Delta Sungai Wulan, Demak

\begin{tabular}{llc} 
Kuadran & \multicolumn{3}{c}{ Stasiun } \\
\cline { 2 - 4 }
\end{tabular}

\footnotetext{
${ }^{\circ}$ Copyright by Management of Aquatic Resources (MAQUARES)
} 


\begin{tabular}{cccc}
\hline & (Jarang) & (Sedang) & (Lebat) \\
\cline { 2 - 4 } & 251,33 & 264,29 & 424,39 \\
2 & 257,39 & 303,95 & 464,28 \\
3 & 192,79 & 269,7 & 388,18 \\
Total & 701,51 & 837,94 & 1276,85 \\
\hline
\end{tabular}

Data penelitian diatas merupakan serasah total atau gabungan yang berasal dari daun, ranting, bunga dan buah yang terjatuh ke dalam litter trap yang kemudian di jumlah untuk dijadikan produksi total serasah mangrove pada setiap kuadran berdasarkan stasiunnya.

Berdasarkan data tersebut didapat bahwa produksi total serasah tertinggi yaitu terjadi pada Stasiun III yang merupakan lokasi dengan kerapatan mangrove yang tinggi, sedangkan untuk hasil terendah terjadi pada stasiun I yang memiliki merapatan mangrove yang rendah. Hal ini menunjukan bahwa tingkat kerapatan memiliki faktor penting dalam menentukan tinggi rendahnya produksi serasah yang jatuh kedalam ekosistem mangrove.

Komposisi dalam produksi serasah mangrove yang dihasilkan terdiri dari 4 komponen utama yaitu ; daun Mangrove, ranting, buah, dan juga bunga. Karakteristik dari jatuhan serasah dari perbedaan spesies mangrove yang berada pada daerah tersebut.

Berikut merupakan serasah mangrove yang terjatuh digolongkan berdasarkan daun, ranting, buah dan juga bunga yang terjadi dalam penelitian selama 5 minggu sebagai berikut :

Tabel 5. Produksi Serasah Mangrove (gram) yang di Hasilkan Selama Penelitian di Delta Sungai Wulan, Demak

$\begin{array}{lll}\text { Stasiun Golongan } & \text { Berat (gram) }\end{array}$

\begin{tabular}{clccc} 
& & Sampling Ke 1 & Sampling Ke 2 & Sampling Ke 3 \\
\hline \multirow{2}{*}{1.} & Daun & 197,4 & 243,9 & 195,69 \\
& Ranting & 20,27 & 1,08 & 9,41 \\
& Bunga/buah & 12,45 & 20,71 & 8,60 \\
& & & & \\
2. & Total & $\mathbf{2 3 0 , 1 2}$ & $\mathbf{2 6 5 , 6 9}$ & $\mathbf{2 1 3 , 7}$ \\
& Daun & 240,01 & 280,98 & 205,37 \\
& Ranting & 1,22 & 6,99 & 46,32 \\
& Bunga/buah & 6,84 & 37,26 & 12,88 \\
& & & & \\
3. & Total & $\mathbf{2 4 8 . , 0 7}$ & $\mathbf{3 2 5 , 2 3}$ & $\mathbf{2 6 4 , 5 7}$ \\
& Daun & 282,42 & 543,17 & 331,39 \\
& Ranting & 40,87 & 32,82 & 25,12 \\
& Bunga/buah & 22,87 & 21,59 & 12 \\
& Total & $\mathbf{3 4 6 , 1 6}$ & $\mathbf{5 9 7 , 5 8}$ & $\mathbf{3 6 8 , 5 1}$ \\
\hline
\end{tabular}

Berikut ini merupakan komposisi produksi total serasah mangrove dari stasiun yang terjadi selama penelitian berlangsung sebagai berikut :
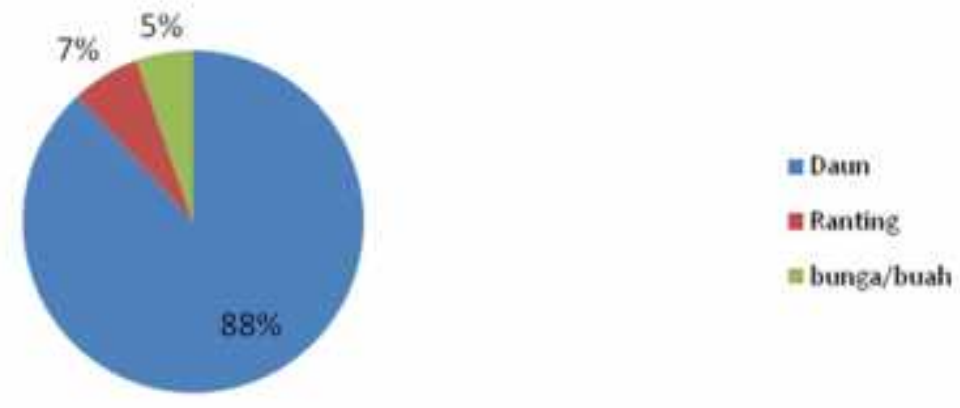

Gambar 2.persentase komposisi total produksi serasah mangrove

Berdasarkan Data tersebut dapat diketahui bahwa sebagian besar serasah yang dihasilkan dari stasiun pengamatan didominasi oleh serasah daun dengan persentasi $88 \%$ pada ke 3 stasiun yang di amati sedangkan serasah yang paling rendah dihasilkan adalah buah/bunga. Hal ini dikarenakan pada bagian buah dan bunga pada 
mangrove memiliki tingkat kemasakan tersendiri dan berbeda antar spesies ini yang menyebabkan rendahnya hasil serasah yang berasal dari bunga atau daun.

\subsubsection{Laju Dekomposisi Serasah Mangrove}

Hasil dari pengurangan berat kering dan laju dekomposisi serasah mangrove yang dilakukan selama 30 hari ini dapat dilihat di Tabel 6.

Tabel 6. Hasil pengurangan berat kering dan laju dekomposisi serasah di Delta Sungai Wulan, Demak

\begin{tabular}{|c|c|c|c|c|c|c|c|}
\hline Stasiun & Kuadran & $\begin{array}{l}\text { Berat awal(gr) } \\
(\%)\end{array}$ & $\begin{array}{l}\text { Hari } 15 \\
\text { (gr) } \\
(\%)\end{array}$ & $\begin{array}{l}\text { Hari 30 } \\
\text { (gr) } \\
(\%)\end{array}$ & Rata - rata & & $\begin{array}{r}\text { B } \\
\text { erdasarkan }\end{array}$ \\
\hline \multirow[t]{6}{*}{ I } & 1 & 30 & 22,64 & 14,37 & \multirow{6}{*}{$\begin{array}{l}15.87 \\
29,47 \%\end{array}$} & & data \\
\hline & & $100 \%$ & $28,49 \%$ & $29,52 \%$ & & & tersebut \\
\hline & 2 & 30 & 27,45 & 13,04 & & & didapatkan \\
\hline & & $100 \%$ & $28,17 \%$ & $29,57 \%$ & & & int \\
\hline & 3 & 30 & 22,99 & 20,19 & & & hasil \\
\hline & & $100 \%$ & $28,47 \%$ & $29,33 \%$ & & & bahwa \\
\hline \multirow[t]{6}{*}{ II } & 1 & 30 & 22,26 & 20,09 & \multirow{6}{*}{$\begin{array}{l}16.56 \\
29,45 \%\end{array}$} & & terjadi \\
\hline & & $100 \%$ & $28,52 \%$ & $29,33 \%$ & & & penurunan \\
\hline & 2 & 30 & 24,96 & 13,50 & & & \\
\hline & & $100 \%$ & $28,34 \%$ & $29,55 \%$ & & & atau \\
\hline & 3 & 30 & 22,01 & 16,18 & & 6 & penyusuta \\
\hline & & $100 \%$ & $28,53 \%$ & $29,46 \%$ & & 0 & n serasah \\
\hline \multirow[t]{6}{*}{ III } & 1 & 30 & 20,58 & 18,78 & \multirow{6}{*}{$\begin{array}{l}14.82 \\
30,42 \%\end{array}$} & & dan laiv \\
\hline & & $100 \%$ & $29,63 \%$ & $30,11 \%$ & & & dan raju \\
\hline & 2 & 30 & 22,66 & 11,81 & & & dekomposi \\
\hline & & $100 \%$ & $29,49 \%$ & $30,61 \%$ & & & si $\quad$ ya \\
\hline & 3 & 30 & 18,88 & 13,88 & & & berbeda \\
\hline & & $100 \%$ & $29,74 \%$ & $30,54 \%$ & & & beda \\
\hline
\end{tabular}

antara setiap kuadran 1, 2 dan 3. Hasil tersebut didapatkan bahwa penyusutan tercepat terjadi pada hari ke 15 atau awal dari proses dekomposisi hal ini dikarenakan bakteri yang membantu laju dekomposisi berperan aktif pada awal proses dekomposisi dan peran bakteri menurun pada hari berikutnya, selain hal tersebut diperkuatkan oleh adanya curah hujan yang tinggi pada minggu ke 2 sampai minggu ke 3 bulan februari. Hal ini diperkuat oleh data curah hujan (BMKG Jawa Tengah Kabupaten Demak,2016)

\subsubsection{Hubungan Tingkat Kerapatan Dengan Produksi dan Laju Dekomposisi Serasah Mangrove}

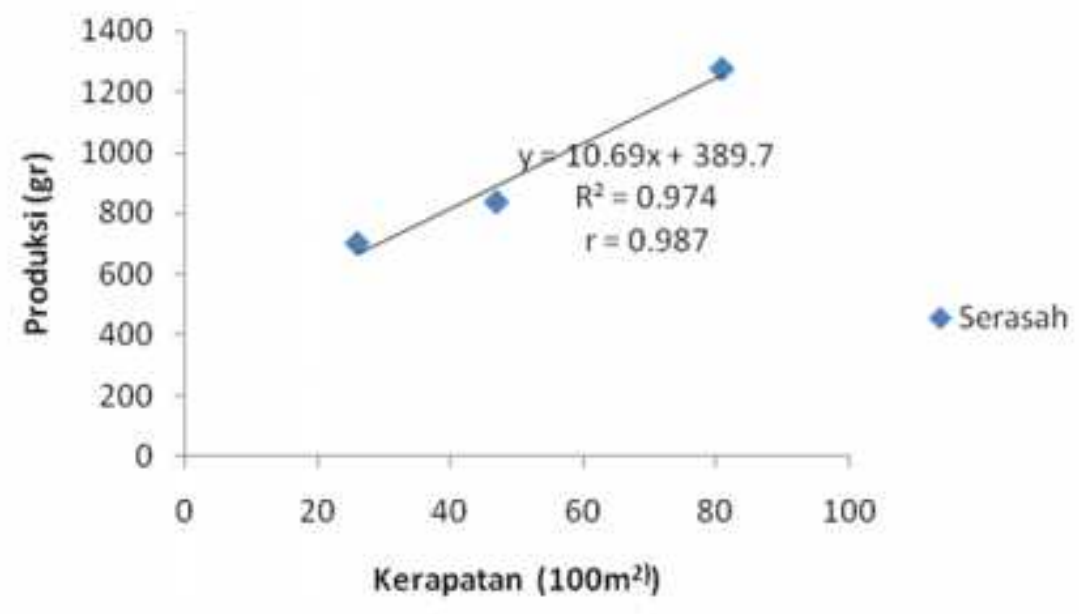

Gambar 6. Hubungan Kerapatan Dengan Produksi Serasah

Berdasarkan jumlah jatuhan serasah yang hasilkan (Tabel 5) maka dilanjutkan dengan uji pembedaanya menggunakan uji regresi untuk melihat pengaruh kerapatan terhadap hasil produksi.Hasil uji diperoleh bahwa jumlah produksi serasah mangrove antar kerapatan berbeda. Hasil uji tersebut memberikan nilai yang menyatakan beda signifikan terhadap stasiun III yang mempunyai tingkat kerapatan tinggi dibandingkan dengan stasiun I dan stasiun II. 


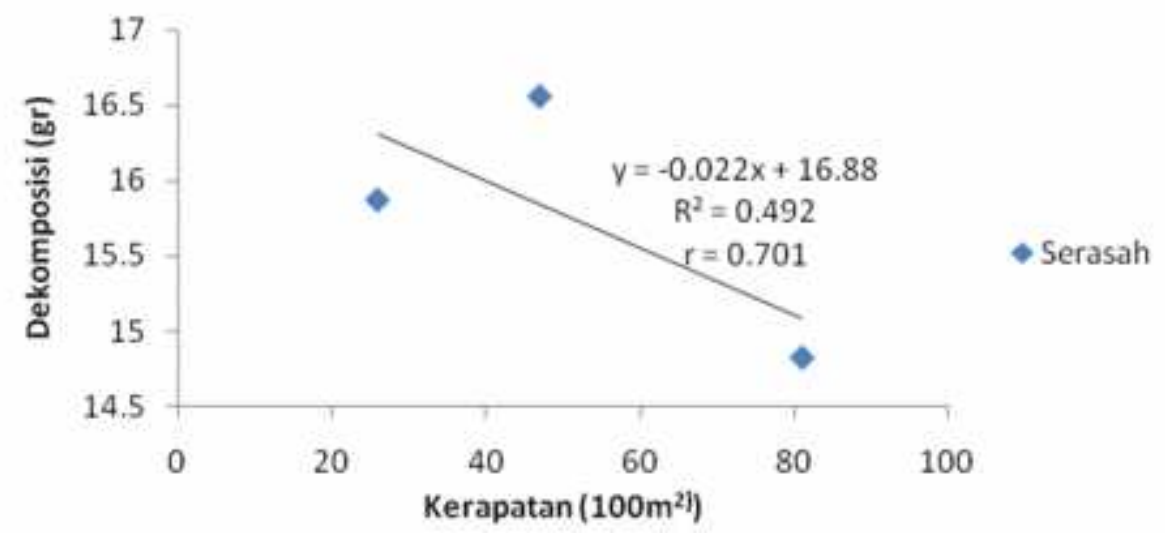

Gambar 7. Hubungan Kerapatan dengan Laju Dekomposisi

Berdasarkan hasil penelitian laju dekomposisi didapatkan bahwa laju dekomposisi tf 7 ggi terdapat pada stasiun III dan yang terendah didapatkan pada stasiun II yang diakibatkan oleh letak dari …....si penelitian yang berbeda dimana pada stasiun III terletak pada daerah pasang surut sedangkan pada stasiun II terletak pada daerah sekitar tambak. Setelah Melakukan Uji analisis ragam, didapatkan bahwa kerapatan mempengaruhi laju dekomposisi serasah mangrove yang dapat diketahui dengan melihat hasil dari pengurangan berat serasah mangrove. Pada stasiun III pengurangan serasah mangrove lebih cepat dibandingkan dengan Stasiun I dan Stasiun II. Hal ini dikarenakan jumlah dari bahan organik yang terdapat pada sedimen lebih banyak terdapat pada mangrove berkategori tinggi, dimana sirkulasi dari daur hidup pada mangrove berkategori tinggi lebih cepat terutama dalam proses pengurain pada detritus terhadap proses dekomposisi serasah mangrove.

\subsection{PEMBAHASAN}

Tingkat kerapatan mangrove berdasarkan stasiun sampling dibedaan menjadi 3 katerogi yaitu : stasiun I dengan kategori rendah, stasiun II dengan kategori sedang, dan kategori tinggi pada stasiun III. Berdasarkan hasil yang didapat bahwa pada tingkat produksi serasah mangrove paling tinggi adalah pada stasiun III hal ini dikarenakan bahwa stasiun III memiliki tingkat kerapatan mangrove yang tinggi yaitu 81 pohon per $100 \mathrm{~m}^{2}$. Menurut Soedarti (2012) bahwa perbedaan hasil yang sangat jelas membuktikan bahwa kerapatan pohon mangrove mempengaruhi produksi serasah, semakin tinggi kerapatan pohon, maka semakin tinggi pula produksi serasahnya. Begitu pula sebaliknya semakin rendah kerapatan pohon mangrove maka semakin rendah produksi serasahnya.

Produksi serasah dalam ekosistem memiliki kegunaan yang sangat penting dikarenakan serasah yang didominasi oleh guguran daun akan jatuh ke tanah mangrove dan akan terurai atau terdekomposisi secara alami, dimana hasil dari dekomposisi tersebut dapat berguna untuk rantai makanan dari ekosistem mangrove. Menurut Mahmudi (2010) bahwa produksi serasah merupakan bagian yang penting dalam transfer bahan organik dari vegetasi ke dalam tanah. Unsur hara yang dihasilkan dari proses dekomposisi serasah di dalam tanah sangat penting dalam pertumbuhan mangrove dan sebagai sumber detritus bagi ekosistem laut dan estuari dalam menyokong kehidupan berbagai organisme akuatik. Hal ini juga diperkuat oleh Siregar (2014) bahwa serasah yang masuk ke perairan mengalami penguraian atau proses dekomposisi, serasah menjadi senyawa organik sederhana dan menghasilkan hara, sehingga dapat langsung dimanfaatkan oleh tanaman. Peran serasah dalam proses penyuburan tanah dan tanaman sangat tergantung pada laju produksi dan laju dekomposisinya.

Serasah mangrove yang jatuh ke dalam tanah didominasi oleh guguran daun - daun dibandingkan dengan ranting, bunga atau buah dari mangrove, hal ini disebabkan karena massa jenis daun yang lebih ringan dibandingkan dengan ranting, buah dan bunga dari mangrove yang menyebabkan mudah gugurnya daun mangrove ke tanah. Menurut Soedarti (2011) bahwa komponen serasah daun lebih sering jatuh dibandingkan dengan komponen serasah yang lain, dikarenakan bentuk dan ukuran daun yang lebar dan tipis sehingga mudah digugurkan oleh hembusan angin dan terpaan air hujan.

Serasah mangrove merupakan hal penting yang dapat digunakan oleh ekosisten untuk menciptakan suatu rantai makan dimana hal ini dimulai dari proses dekomposisi serasah mangrove, serasah mangrove yang terdekomposisi kemudian akan digunakan oleh mikroorganisme yang menggunakan serasah tersebut untuk bahan makanan. Menurut Nurgaya (2013) bahwa mangrove sebagai salah satu produsen pada kehidupan perairan telah memberikan sumbangan yang sangat berarti terhadap biota perairan, salah satunya sebagai penyuplai unsur hara untuk pertumbuhan plankton. Unsur hara yang dimaksud berupa daun-daun kering, patahan-patahan ranting yang kemudian mengalami dekomposisi serasah yang mengalami mineralisasi dan menghasilkan hara nantinya dimanfaatkan oleh plankton sebagai bahan dalam proses fotosintesis. 
Serasah mangrove merupakan sumber utama nutrisi dan bahan organik ke sistem perairan pesisir Nga et. al. (2006) dalam Nurgaya (2013). Serasah pada suatu ekosistem mangrove setelah mengalami dekomposisi sangat penting artinya untuk perikanan pantai karena ekosistem mangrove menyediakan bahan makanan bagi spesies ikan nantinya dijadikan tempat berlindung larva ikan-ikan lokal Acosta et. al. (1999) dalam Nurgaya (2013).

Lingkungan yang mempengaruhi dari produksi dan laju dekomposisi terdapat beberapa faktor diantaranya curah hujan dan kecepatan angin, temperature, salinitas dan $\mathrm{pH}$ tanah, tekstur sedimen, bahan organi. Hal ini Menurut Siregar (2014) bahwa dekomposisi serasah terjadi karena beberapa fa 8 seperti jenis tanah, tingkat salinitas, pH tanah, temperature lingkungan, kandungan dalam bahan tanaman dar ${ }^{8}$-lain.

Berdasarkan hasil tersebut didapatkan bahwa tingkat produsi serasah tertinggi terjadi pada pertengahan bulan februari merupakan puncak musim hujan dengan kategori ringan sampai lebat Menurut Data BMKG (2016), di Lampirkan pada (Lampiran 5). Hal ini disebabkan bahwa tingkat produktifitas dari serasah mangrove sangat dipengaruhi oleh faktor cuaca, disaat musim hujan produksi serasah lebih tinggi dibandingkan dengan musim kemarau disebabkan karena rendahnya massa jenis daun yang membuat daun mudah jatuh kedalam peairan atau tanah mangrove. Hal ini diperkuat oleh Soedarti (2011) produksi serasah tertinggi terjadi pada saat musim hujan atau pada saat curah hujan mencapai tinggi. Selain itu faktor yang mengakibatkan tingginya produksi serasah adalah faktor musim dan kecepatan angin.

\section{KESIMPULAN}

Berdasarkan penelitian produksi dan laju dekomposisi serasah mangrove berdasarkan tingkat kerapatan di delta sungai wulan demak, Jawa Tengah dapat disimpulkan Sebagai berikut :

1. Jumlah produksi serasah mangrove berbeda pada wilayah kerapatannya pada setiap stasiun memiliki nilai yang berbeda hal ini diakibatkan oleh adanya pengaruh dari tingkat kerapatan. Produksi serasah tertinggi berada pada Stasiun III dengan kerapatan tinggi yaitu dengan 1276.85 gram, diikuti Stasiun II dengan kerapatan sedang 837.94 gram dan Stasiun I dengan kerapatan rendah 701.51 gram.

2. Laju dekomposisi serasah mangrove berbeda antar kerapatan. Pada stasiun III dengan mangrove rapat sebesar $30.42 \%$, diikuti stasiun I dengan mangrove yang jarang sebesar $29.47 \%$ sama dengan stasiun II dengan mangrove sedang sebanyak $29.45 \%$.

3. Kerapatan pada mangrove mempengaruhi dari hasil produksi serasah dan laju dekomposisi, dimana stasiun III dengan mangrove rapat memiliki hasil produksi tertinggi dan terendah pada stasiun I dengan mangrove yang jarang sedangkan pada laju dekomposisi stasiun III mengalami dekomposisi tertinggi dan terendah tasiun I dan II.

\section{Ucapan Terimakasih}

Penulis mengucapkan terimakasih kepada Dr. Ir Haeruddin, M.Si, Dr. Ir Bambang Sulardiono, M.Si dan Dr. Ir Suryanti, M.Pi yang telah memberikan masukan dan saran. Terimakasih pula penulis ucapkan kepada pihak - pihak yang telah membantu dalam penyusunan penelitian.

\section{DAFTAR PUSTAKA}

Bengen, D. G. 2003. Pedoman Teknis Pengenalan dan Pengelolaan Ekosistem Mangrove.PKSPL.IPB. Bogor

Indriani, Y.2008. Produksi dan Laju Dekomposisi Serasah Daun Mangrove Api - api (Avicennia marina Forssk. Vierh) di Desa Lontar, Kecamatan Kemiri, Kabupaten Tangerang, Provinsi Banten.[Skipsi] .Fakultas Perikanan dan Ilmu Kelautan.Institut Pertanian Bogor.

Mahmudi , M. 2010. Estimasi Produksi Ikan Melalui Nutrient Serasah Mangorve di Kawasan Reboisasi Rhizopora, Nguling, Pasuruan, JawaTimur.Jurnal Ilmu Kelautan.Vol 15(4):231-235

Nurgaya,W., Ramli, M dan Sa'ban. 2012. Produksi dan Laju Dekomposisi Serasah Mangrove Dengan Kelimpahan Plankton di Perairan Mangrove TelukMoramo. Jurnal Mina Indonesia.Vol 3:132-146.

Siregar, T. Yunasfi. Albino P. 2014.Laju Dekomposisi Serasah Daun Rhizopora mucronata dan Kontribusinya terhadap Nutrisi di Perairan Pantai Serambi Deli Kecamatan Labu. Jurnal Faktultas Pertanian, Universitas Sumatra Utara.

Steel, R. G. D., dan J.H. Torrie, 2009. Prinsip dan Prosedur Statistik Suatu Pendekatan Biom 9 Penerjemah Sumantri. Gramedia Pustaka. Jakarta 
Susilowati, A.,Winarno, K. Wiryanto. Indrowuryatno danA.D. Setiawan.2005. Tumbuhan Mangrove di Pesisir Jawa Tengah : 2. KomposisidanStruktur Vegetasi. Jurnal Biodiversitas.Vol 6(3):194-196.

Susilowati, A., Winarno, K. Wiryanto. Indrowuryatno dan A.D. Setiawan., 2008.Tumbuhan Mangrove di Pesisir Jawa Tengah 3. Diagram Profil Vegetasi. Jurnal BiodiversitasVol 9(4):315-321.

Sulistyowati, H.2009. Biodiversitas Mangrove Di Cagar Alam Pulau Sempit .Jurnal Sainstek, Vol 8(1):59-64.

Soedarti T, T Widyalekson,danA.G. Sopana.2012 Produktifitas Serasah Mangrove Dikawasan Wonorejo Pantai Timur Surabaya.Jurnal Fakultas Sains dan Teknologi, Universitas Airlangga, Surabaya. 